\title{
Mining as Canadian Nation-Building: Contentious Citizenship Regimes on
} THE Move

\author{
Max Chewinski
}

Abstract. This article presents Canadian mining abroad as an imperial, nationbuilding practice that can be traced to state discourses. In analyzing state discourses, it is argued that an ideal citizenship regime is constructed, in part, due to a specific set of values and identities. This citizenship regime is corporate in nature, and operates as a vehicular idea that facilitates the flow of travelling technocrats, minerals and capital by reshaping the policies and practices of host nations. In the discourses examined, it becomes clear that the Canadian state actively forms both the conditions for the expansion of nation-building projects and actively participates in securing and promoting contentious mining projects. By mobilizing corporate citizenship, Canada remains committed to managing resistance movements that pose a risk to accumulation instead of addressing corporate impunity. The article concludes by considering how MiningWatch Canada and the movements they support create fissures in the corporate citizenship regime.

Keywords: Nation-building, mining, citizenship regime, policy mobility, Canadian imperialism

Résumé. Cet article suggère qu'à l'étran ger, l'industrie minière canadienne constitue une pratique impérialiste contribuant à l'édification nationale, dont on peut retracer l'origine aux discours étatiques. Par une analyse de ces discours étatiques, il est soutenu qu'un ensemble de valeurs et d'identités sert, en partie à construire un idéal citoyen. Ce régime de citoyenneté est celui par nature de l'entreprise, et il opère de manière à véhiculer des idées qui facilitent le flux des technocrates, des minéraux et des capitaux mobiles, en réorganisant les politiques et les pratiques des nations qui possèdent des ressources minérales. Les discours étudiés font apparaître la façon dont l'État canadien joue un rôle actif dans la formation des conditions nécessaires à l'expansion de projets d'édification nationale et participe à la mise en œuvre et à la promotion de projets miniers controversés. En mobilisant ce régime de citoyenneté entrepreneuriale, le Canada maintient son engagement à gérer des mouvements sociaux de résistance qui mettent en danger les pratiques d'accumulation plutôt que de lutter contre l'impunité des entreprises. L'article conclut en examinant la façon dont MiningWatch et les 
mouvements sociaux soutenus par cette organisation parviennent à fissurer ce régime de citoyenneté entrepreneuriale.

Mots clés: Edification nationale, extraction minière, régime de citoyenneté, mobilité des politiques, impérialisme canadien

\section{INTRODUCTION}

T he mobilities turn has challenged the social sciences to reconsider the sedentarist theories adopted to interpret the social world, claiming that such theories reify bounded places or nations as the basic units of social research (Sheller and Urry 2006). This approach focuses on the spatial mobility of humans, objects and non-humans; the circuits that transmit capital, images and information; and the moorings and technologies facilitating travel and flow (Sheller 2014). In other words, the mobilities turn asks that sociologists dispense of a bounded conception of society (Urry 2000) in favour of a relational ontology taking seriously the co-constitution of subjects and meanings (Sheller 2014), including the mobile policies and vehicular ideas governing interactions between technocrats and the publics they encounter (Peck 2011; Temenos and McCann 2013). ${ }^{1}$ Novel approaches to theorizing mobilities include analyses of the forms of governance enabling movement, as well as the meanings, ideologies and representations attached to such processes (Sheller 2014).

In this paper, I examine the role of Canadian imperialism in facilitating the global movement of minerals, capital and policies to expand its nation-building practices. In doing so, I pay close attention to the Canadian citizenship regime as a governance system driving the movement of particular policy knowledge, approaches and models from one place to another (policy mobility) and the rise of corporate citizenship as a flexible and vague (vehicular) idea facilitating the fast transmission, reformulation and adoption of policies that consequently remake the landscapes of host country territories. This represents a shift away from current research on natural resources and mobility (Campbell 2012; Pedersen and Bunkenborg 2012) by moving from an examination of the

1. As with previous scholarship (Larner and Laurie 2010; Temenos and McCann 2013), I use travelling and middling technocrats to refer to actors that play a critical role in spreading and reshaping policy at local, national, and/ or international levels. Travelling/middling technocrats are involved in processes that anchor globalization (Larner and Laurie 2010) - or, as argued in this paper, imperialism - in host nations by promoting neoliberal (mineral) policy reform and by privatizing social and environmental concerns. 
routes (roads) of colonial resource acquisition to the relationship between Canadian mining as a nation-building practice and the values, ideals and identities driving citizenship regimes. ${ }^{2}$ It also applies vehicular ideas in a unique way, as the concept is typically used in mobilities scholarship to analyze local-level policies addressing sustainable development in education (McKenzie, Bieler and McNeil 2015), creative cities (Peck 2012), and housing first models (Baker and Evans 2016) as opposed to the movement of policy across various scales (from nation to nation, and diffused down to individual communities) and networks (including corporate actors, government officials and development organizations).

As a type of governance, citizenship regimes include the understandings, institutional rules and arrangements shaping state policy, direct state expenses, allow the state and citizens to define problems as well as guide citizen claim-making (Jenson 2001/2007). ${ }^{3}$ If citizenship regimes are integral in constructing the political rationalities informing governance (Brodie 2002a), then an analysis identifying these elements in the context of Canadian mining practices is crucial to understand the current level of engagement in this process by the state, corporate actors, as well as civil society organizations and the anti-mining struggles they support. I adopt Jenson's (2001/2007) citizenship regimes to account for the values and responsibilities attached to mining as an imperial practice of nation-building and to understand how nation-building and national identity are worked out through state discourses in support of an ideal citizenship regime framed as corporate in nature. In the process, I expand this analytical tool by highlighting the mobile dimension of citizenship regimes.

As a vehicular idea crafted by the Canadian state, corporate citizenship effectively masks the mobile policies reconstituting fields of power abroad (Peck and Theodore 2010; Peck 2011; Temenos and McCann 2013) through a corporate social responsibility rhetoric. This citizenship regime is occurring in an era marked by neoliberal restructuring in which the new Canadian imperialism (Klassen 2009/2014; Shipley 2013) provides for the movement of technocrats, capital, values and sets

2. Yashar (2005) has written on mining in relation to citizenship regimes, but not of Canadian mining companies in particular.

3. The four dimensions of a citizenship regime include: (1) delineating the appropriate values and responsibilities that give character to a state as well as shape its responsibilities vis-à-vis the market (2) demarcating the border and boundaries signifying both inclusion and exclusion in the political community (3) dictating the governance arrangements of a state and (4) contributing to selective definitions of membership, including definitions of nation-building, identity and the construction of ideal citizenship forms (Brodie 2002a; Jenson 2007). 
of practices altering the policies of host nations, resulting in community conflict. In solidarity with impacted communities and movements from below, non-state actors such as MiningWatch Canada (MWC) ${ }^{4}$ articulate alternative discourses and practices contesting and redefining the substance of citizenship regimes. Although the state previously receded to the shadows of entrepreneurial citizenship (Brodie 2002a; 2002b), this paper argues that the current character of the Canadian state operates according to an imperial model. In this model, the Canadian state actively forms the conditions for the expansion of mining projects and actively participates - through 'middling' or 'travelling' technocrats and the deployment of vehicular ideas - in dynamic networks of interaction reshaping foreign resource governance policies. These processes shape a corporate citizenship regime driven by: "Canadian" values, appeals to historical identity formations, and governance arrangements that not only deflect responsibility from the state by refusing to significantly influence the conduct of corporate actors but also attempts to manage the risks posed by anti-mining resistance movements.

This paper is divided intro three sections. First, I discuss the importance of Canadian nation-building by exploring the scalar extension of economic practices in the current period marked by the hypermobility of capital. Second, by critically analyzing the 2013 Speech from the Throne (SFT) and Canada's voluntary foreign policy on corporate interactions abroad, I discuss how these discourses shape the construction of a corporate citizenship regime. ${ }^{5}$ Situated within a larger context of Canadian impunity, the third section includes a vignette of an anti-mining struggle in Mexico that highlights what a corporate citizenship regime driven by the new imperialism entails in practice. This section concludes by discussing how civil society actors contest this encroaching corporate citizenship regime, and provides insight for future research trajectories.

4. MWC was selected because it has the capacity and resources to engage in information politics, which includes disseminating information through the generation of reports (Keck and Sikkink 1998). It is important to note that there is growing grassroots mobilization in Canada as the result of the effort of groups such as Mining Injustice Solidarity Network and Mining Justice Alliance.

5. SFT are robust measures of the policy priorities, agendas and cultural dynamics of a given Government (Jennings, Bevan and John 2011; John and Jennings 2010) and are significant discourses for tracing the mobility of policies in securing international influence. 


\section{Mining, Canadian Nation-Building and the New Imperialism}

Classical studies of nation-building view nations as "imagined communities" (Anderson 2006) with a shared identity and invented traditions (Jackson 2015). More recent theorization has added to this cultural understanding an economic dimension, suggesting a state's legitimacy is, at least in part, based on securing "rights to a share in the material and symbolic resources that define the nation" (Jackson 2015; Penrose and Mole 2008: 278). In order to demonstrate this, states support domestic industries as a means of unification through "symbols of economic development" (Jackson 2015: 439). Canada is not exempt from this nation-building process: early mining departments branded mineral extraction as a practice in the public interest and past initiatives such as John Diefenbaker's "Road to Resources" were designed to build and legitimate Canada's resource sector (McAllister 2007). In Canada, building a mineral nation requires the adoption of foreign policies such as Building the Canadian Advantage (BCA 2009) and its most recent iteration, Doing Business the Canadian Way (DBCW 2014). ${ }^{6}$ Such policies result in the diffusion of Western understandings of development, facilitating neo-liberal deregulation abroad and the entry of corporations into "new resource frontiers" (Jackson 2015).

The expansion into new frontiers is not to say Canada no longer develops its own natural resources. In fact, the opposite is the case - the production and export of minerals generated $\$ 89.5$ billion in merchandise exports, accounting for a total of 21 per cent of overall exports in 2012 (NRC 2013). However, despite the continuing importance of mineral extraction within the territory and boundaries of the state, international mining ventures enlarge the scale and scope of natural resource production. This process demonstrates Canada's commitment to expanding and securing economic growth vis-à-vis exploitation and political domination, suggesting Canada is increasingly an imperial power independent of the United States (Burgess 2002; Klassen 2009/2014; Shipley 2013). This new Canadian imperialism (Klassen 2009/2014; Shipley 2013) is marked by increasing capital accumulation and internationalization through Canadian direct investment abroad (CDIA); the formation of a distinct Canadian capitalist class cooperating and competing with the

6. In consultation with civil society organizations and extractive sector stakeholders, both documents were produced by Global Affairs Canada to outline a corporate social responsibility strategy for companies engaging in resource extraction abroad. The documents impress upon companies a series of voluntary best practices that are to reflect Canadian values and ethical standards. 
United States and a process of neoliberal state restructuring in which foreign policy is created to support dominant class interests. ${ }^{7}$

The new imperialism has resulted in flows of CDIA surpassing inward flows of capital as of 1995/96 (Burgess 2002; Klassen 2014). This trend of increasing CDIA has been a strategy endorsed by both governments and larger multinational firms with longitudinal trends suggesting CDIA in energy and metallic minerals is second to finance and insurance (Holden 2008; Klassen 2014). In fact, Natural Resources Canada (2012) indicates that Canadian firms have a "strong external investment presence." Indeed, in 2013 metallic minerals accounted for 18 per cent of CDIA (Tremblay 2014), indicating the global expansion of mining firms (Klassen 2014). In regards to Canadian markets, the Toronto Stock Exchange (TSX) and the TSX Venture Exchange (TSXV) facilitate 90 per cent of global equity financing for mining exploration and production with approximately half of the exploration projects facilitated by these exchanges located outside of Canada (Kamphuis 2012). ${ }^{8}$ This type of policy retains investment in Canada and acts as an incentive for Canadians to invest in the mining industry (Dougherty 2013). These figures attest to two related phenomena: first, the global mobility of nationbuilding projects via investment practices and second, the position of Canada as a hegemon in the global mining industry.

\section{State Interventions: Constructing Canadian (Corporate) Citizenship, Identity and Values}

The meaning and ontological nature of citizenship has been historically tied to the boundaries of the state (Brodie 2002b). However, as Turner (1993) suggests, citizenship is more than a bounded legal status, constituting a "set of practices (juridical, economic and cultural) which define

7. This definition is similar to citizenship regimes in that both concepts have overlapping elements (policy and governance). I adopt both because they are complementary: citizenship regimes stress the cultural component of the new imperialism (explicitly including values, national identity and nation-building as significant), while the new imperialism pays more attention to the role of capital and class in policy and governance. Combined, the two provide a more comprehensive explanation of how Canadian mining operates, its class and corporate character, as well as the values and ideas driving Canadian (corporate) citizens and technocrats.

8. The reason the TSX/TSXV raises such a large amount of capital for mining is due to efforts on behalf of the Canadian state to "gain control over mineral value chains" by creating laws that subsidize companies via a flow through tax credit that "makes 100 per cent of capital invested in domestic junior activity tax deductible for the investor" (Dougherty 2013: 349). 
a person as a competent member of society" (as cited in Brodie 2002b: 379). In expanding this understanding, Urry (2000) comments that such practices not only occur within and outside of bounded nation-states, but that citizenship in an era marked by human mobility results in the fundamental contestation of the rights and responsibilities of citizens on the move (Urry 2000). In accordance with the citizenship regime framework outlined previously, these sets of practices are linked to a "particular understanding of nation, nation-building and national identity" (Brodie 2002b: 379). Although citizenship cannot be reduced to these particular understandings, they are nonetheless an important component of state discourses because they outline "who and what is demobilized and remobilized across many different scales" (Sheller 2014: 794). For the Canadian citizenship regime, ideal types of citizenship predicated on the rights of transnational corporate actors are remobilized, while the rights to citizenship forms rooted in justice and sustainability are demobilized.

The avenue the state uses in constructing this form of citizenship and its corresponding sets of practices and rights is reflected in Speeches from the Throne and various government documents that link certain constructions of "Canadianness" to economic initiatives. State discourses such as the SFT are fertile ground for examining the power of both discourses and practices, particularly in terms of how they produce the effects of movement (Sheller 2014). In examining these discourses below, I suggest that although Brodie's (2002a; 2002b) entrepreneurial citizen does exist, the focus on individual entrepreneurs tends to obscure the active role of the state in the new Canadian imperialism and its accompanying corporate citizenship regime, the latter of which usurps "Canadian" identity and values for the movement of minerals and capital.

In this process, corporate citizenship emerges as a vehicular idea (McKenzie et al. 2015; McLennan 2004; Osborne 2004; Peck 2012) facilitating imperial conquest. Borrowing from Osborne (2004), McLennan (2004: 485) states that vehicular ideas are adopted as a means of "moving things on" from point A to B. Vehicular ideas, as a consequence of their mobility, become concepts that are contextually flexible yet discursively exclusive and tend be vague and open-ended (McKenzie et al. 2015; McLennan 2004; Peck 2012). Vehicular ideas shift in meaning and interpretation as a result of ownership and this is due to the ideologies and practices of the diverse actors constituting the user network. As will be described below, corporate citizenship as a vehicular idea is adoptedand adapted on the receiving end - by travelling technocrats transferring policies to reconfigure governance arrangements in favour of Canadian imperialism and nation-building. 
Speeches From the Throne: Mobilizing Values to Seize Land and Gain Access to Minerals

Speeches from the Throne are important discourses because they outline the goals and directions of governance in Canada, and provide valuable insight into the constructions of Canadian identity and its associated values. Canadian values and identity are important for citizenship because they are often used by the state to construct an ideal citizenship form that softens the image of (mining) corporations in the eyes of the public, the international community and prospective host nations. Brodie (2002a) provides an in-depth analysis of SFT for much of the $20^{\text {th }}$ century in Canada, but only the SFT of the 1980s onwards are worth mentioning for the purposes of this paper. In particular, these SFT address and reflect the process of imperial globalization and view Canadians as citizens actively engaging in it (Brodie 2002a: 62). As Brodie (2002a: 62) notes, these SFT relied on "our national tradition and value structure: Canada's history is the history of builders and achievers." These "builders and achievers" are well suited for global competition because of the characteristics of Canadian national identity: "our country has a tradition of being a responsible, engaged, [and] committed world citizen" (Brodie 2002a: 62).

The 2013 SFT attributes an active role to the state otherwise absent from previous SFT or scholarly analyses (Brodie 2002a; 2002b). This role becomes apparent in some of the 142 instances in which "our government" is utilized to discuss the intentions and/or actions taken by the state to plan, administer and/or amend social services or economic initiatives in and outside of Canada (SFT 2013). Examples of this in the SFT (2013: 6-7) include our government "is...committed to expanding trade with emerging markets" and "will launch a comprehensive new plan to assist Canadian businesses as they expand abroad." These statements suggest the state has not receded into the background - into the shadows of entrepreneurial citizens - but plays a primary role in facilitating access to, and creating favourable conditions for, corporate citizens engaging in the national and global economy.

The role of the state is not only apparent in these aforementioned statements, but in the title of the document itself: Seizing Canada's Moment: Prosperity and Opportunity in an Uncertain World (2013). Semantically, the verb seizing in this title is important in the context of nationbuilding projects. The word appears (in different forms) in the text and is used in contexts reminiscent of the aphorism carpe diem, or 'seize the day'. The difference in this circumstance is that it signifies a contemporary economic opportunity for securing prosperity for the Canadians of 
today and tomorrow (SFT 2013). As will be discussed later, much of the means invoked in securing mining exploration or production occurs in an atmosphere in which land itself is seized; it is forcefully removed from the control of local (often indigenous) populations without consent or significant consultation. This is surprising in light of the image portrayed of Canadian identity and values in the SFT (2013). This is an image of Canadians as "honourable people of peace" that are selfless, caring and sustained by "mutual interdependence" (SFT 2013: 1-2). According to the SFT (2013: 19), Canadians "stand for what is right and good in the world" and "seek a world where freedom - including... democracy and human dignity are respected." These values are to be promoted by the government and its partners in the private sector in an effort to "help the world's neediest" (SFT 2013: 19), forming the substance of the corporate citizenship regime articulated below.

\section{Corporate Citizenship: Creating a Caring Capitalism?}

Globalization has allowed for the evolution of citizenship as a legal and political concept, with transnational corporations growing and maturing in this period of increasing trade, foreign direct investment and business expanding outside the confines of the nation-state (Palacios 2004). The corporate citizen emerges as a new form of citizenship transgressing national boundaries. Corporate citizenship is "analysed in terms of moral values and ethical arguments," but is increasingly being associated as incorporating the best business practice approach (Palacios 2004: 391). This conceptualization of corporate citizenship is essentially tied to Corporate Social Responsibility (CSR) principles, but with an emphasis added on meeting responsibilities, thus making it performance-oriented (Matten and Crane 2005; Thompson 2005). It is guided by a "social responsibility thesis" and directed by the doctrine of "caring capitalism" (Palacios 2004: 391). The substance of this thesis is that it is beneficial (profitable) for corporations to operate in a responsible manner by being respectful of workers' rights, protecting the local environment, and abiding by local, regional, national and international laws (Palacios 2004). It is through this philosophy and its associated practices that corporations gain their legitimacy and public trust (Palacios 2004).

In analyzing CSR practices of Canadian mining companies, Coumans (2012: 47) finds this brand of corporate citizenship inadequate in responding to social, environmental and cultural harms experienced by impacted communities and unable to address the issue of 'laggards': "companies that choose not to apply best practice standards at all, or do not apply them consistently at a particular operation, or uniformly across 
all operations." The inadequacy of corporate citizenship is in part due to the purposive mutability of vehicular ideas (Peck 2012). Corporate citizenship and the CSR regime it advocates is not a fixed template for how to engage in responsible mining, but a voluntary and fluid framework that can be reorganized according to contextually specific means and ends (Peck 2012). As a vehicular idea that is not only ambiguous but also voluntary to ensure smooth travel, its commitment to the doctrine of a caring and progressive capitalism is challenged. In spite of this contradiction, it has been adopted by the Canadian state as the exemplary approach to doing business abroad.

Driven by a distinct Canadian capitalist class (Klassen 2014; Shipley 2013), the citizenship regime operates as an imperial force encouraging citizens to seize the opportunity before them by mobilizing "Canadian" values and leading the global community into an era of wealth and prosperity (SFT 2013). Corporate citizenship's appeal to Canadian values, national identity and an historic commitment to nation-building is reflected in the policies shaping Canadian citizen conduct abroad. The policies described in the following section are rendered mobile and transformed as they are adapted and negotiated at various spatial settings and networks that include corporate actors, state departments, development non-governmental organizations (NGOs) and the middling technocrats described in the literature (McKenzie et al. 2015; Temenos and McCann 2013). In the process, the object of governance becomes the resistance movements posing a risk to nation-building projects. This becomes most evident in the two strategies created to guide the Canadian mining operations abroad.

\section{Middling Technocrats and the Corporate Citizenship Regime}

The most prominent state strategies outlining the role of corporations in the extractive industry include BCA (2009) and DBCW (2014). In travel, and through the practices of both Canadian technocrats and corporate citizens, the policies contribute to the neoliberal transformation of host nation resource policies by promoting a "radical embrace of volunteerism" (Kamphuis 2012: 1466) in which Canadian corporate citizens "manage social and environmental risks" (BCA 2009). This indicates the primary object of governance is not the corporate citizen involved in these nation-building activities, but the groups posing a threat to the mobility and accumulation of capital and minerals. Framed in a different manner, Kamphuis (2012: 1481) notes that this policy perceives communities and the civil society actors working with them as risks needing to be managed. The risk manage- 
ment policy of BCA (2009) is expressed through the establishment of the Office of the Extractive Sector CSR Counsellor.

The Counsellor's role is to assist all stakeholders involved in a dispute of CSR issues in a voluntary resolution process. This prospect appears fruitful, but the lack of success in resolving issues is concerning as all cases have been dismissed with at least three of the six cases closed as the result of a mining company withdrawing from the process (Do 2014). Although the state prides itself in its CSR policies, notably stating that responsible corporations play an "important role in promoting Canadian values internationally and contribute to the sustainable development of communities" (Global Affairs n.d.-a: para. 1), the lack of engagement on behalf of corporate citizens contradicts the Canadian values that are supposed to underpin them: a caring nature, respect for human dignity and the promotion of democratic processes. This strategy for a corporate citizenship regime rooted in voluntary practices has not been strengthened with the introduction of DBCW (2014).

The "improved" DBCW (2014) strategy is perceived by an assemblage of state actors as a stronger mandate detailing the desired approach to be adopted by corporate citizens in operating abroad. However, this strategy promotes the same voluntary corporate citizenship regime presented in the initial document with a few minor additions. The updated and supposedly more comprehensive approach to CSR can be achieved by strengthening four sets of activities, two of which will be examined: (1) fostering networks and partnerships and (2) facilitating dialogue towards dispute resolution. ${ }^{9}$ As will be discussed below, these two activities demonstrate the state's resolve in avoiding a strong regulatory approach.

In terms of fostering networks and partnerships, the Canadian state is expecting to further its convener role in the extractive industry by facilitating the creation of dense networks operating at various spatial configurations and with competing actors. In doing so, policy pushers/technocrats engage in the reformulation and diffusion of policy. Practically speaking, this includes middling technocrats connecting "companies with practitioners in the areas of social, environmental and economic performance, as well as creating dialogue spaces and venues for bridge-building between companies, communities, and other interest groups" (DBCW 2014: 9). While this approach appears comprehensive, it is largely driven by the desire to secure mineral

9. The remaining two activities include promoting CSR guidance and enhancing the (investment) environment affecting responsible business practices (DBCW 2014). 
value chains and Canada's commercial interests as outlined in its economic diplomacy policy, and BCA (2009).

The imperial character of the DBCW (2014: 9) strategy is made visible by the recognition that Canada's Trade Commissioner Service (TCS), in partnership with Canada's diplomatic missions, will proactively assist companies in managing environmental and social risks by "helping to solve problems and assisting with market preparation and assessment" at all levels of the development of extractive projects. These initiatives appear well-meaning, but are concerning as they operate according to the belief that development projects will be approved, irrespective of a community's own development needs. In fact, it is the responsibility of Canada's commercial actors to manage risk, including community resistance, through a mediatory role by providing CSR material for companies, advice on community relations, and linking companies to development organizations to persuade communities to accept projects - often by offering to support "initiatives in health, education [or] local economic growth" (DBCW 2014: 10). The problem with this approach is that it suggests that resource extraction is inevitable, entrenching Canadian imperialism and effectively denying the rights of a community to refuse development projects.

The DBCW (2014) strategy for facilitating dialogue towards dispute resolution is striking in its commitment to a failed initiative: utilizing non-judicial dispute resolution mechanisms, namely through the CSR Counsellor. While the mandate of the Counsellor remains the same, it includes an additional step in the dispute resolution process: in cases where disputes could "benefit from formal mediation", the CSR Counsellor will encourage parties to seek help through Canada's National Contact Point (NCP) for the OECD Guidelines for Multinational Enterprises. Both the CSR Counsellor and the NCP have failed to resolve conflicts in the past (Coumans 2010: 43), calling into question the willingness of the Government to seriously commit to its stated values. However, the Canadian state appears to be slowly embracing a more firm position with its companies by withdrawing activities associated with economic diplomacy should a particular company fail to embody CSR practices and/or refuse to participate in the voluntary dispute resolution process. Unfortunately, this initiative does not make use of the state's power to withdraw its financial support of Canadian companies through Export Development Canada 
(EDC), but only cites the possibility of withdrawing financial support (DBCW 2014: 13). ${ }^{10}$

The Canadian position is clear: doing business the Canadian way includes voluntary commitments to stated values and practices, with public regulation and any prospect of legal remedy inconceivable. Instead, by mobilizing corporate citizenship as a vehicular idea and in deploying travelling technocrats abroad, Canada remains committed to the conquest of foreign mineral markets, operating through dense networks to secure licenses facilitating the flow of capital, resources and citizenship regimes governing the product of nation-building (anti-mining resistance) as opposed to the source of the problem (the imperial practices and classes driving resource exploitation).

\section{Contesting Corporate Citizenship: Regimes from Below and Beyond the State}

As a component of both the new imperialism and a corporate citizenship regime, Canadian mining may operate with impunity, but certainly not without resistance (Gordon and Webber 2008; Pederson 2014; Rasch 2012; Shipley 2013). Social movements in Latin America continue to resist Canadian mining projects as they encounter the vehicular idea of corporate citizenship and the travelling technocrats facilitating imperial development. In northeastern Guatemala, former Canadian Ambassador James Lambert stated "through sustainable development of our mining resources, these communities are creating the economic, cultural and social infrastructure necessary to secure their futures and the future of their children." (Pedersen 2014: 194). This promise of future prosperity

10. I am referring here to the efforts of the previous majority government held by the Conservative Party. With the new governing Liberal Party, it is too early to provide a thorough assessment of how it will approach the Canadian extractive industry abroad. In the past, the Liberal Party have supported unsuccessful attempts to make Canadian resource companies abroad more accountable by introducing private member's Bill C-300: An Act respecting Corporate Accountability for the Activities of Mining, Oil or Gas in Developing Countries. However, at the time of writing this manuscript and since taking office in November 2015, neither Trudeau or Dion have signaled a change in the government's approach to Canadian extraction abroad, despite opportunities for doing so in the 2016 Federal Budget (by redirecting funding away from the CSR Counsellor's office to an independent Ombusdman) or in drafting the priorities of the new Global Affairs Canada (which, at this point in time, does not list the regulation and accountability of Canada's resource sector abroad as a priority) (Global Affairs n.d.-b). The absence of international resource governance in discourses and priorities suggests that business will carry on as usual. 
has not convinced local communities outside of Vancouver-based Radius Gold's El Tambor mine to accept the project, and an enduring blockade and resistance movement continues to halt mining in the region (Pedersen 2014).

In Honduras, following a military backed coup against the antimining President Zelaya, Canadian technocrats (including Ambassador Cameron MacKay, representatives from the now defunct Canadian International Development Agency and Canadian mining company Breakwater Resources) lobbied the Lobo government to reverse the moratorium on open-pit mining, reduce corporate taxes, limit public consultations and remove environmental protections to streamline mineral exploitation (Shipley 2013). This lobbying occurred despite immense opposition, with 90 per cent of the Hondurans polled in 2011 indicating they are against open-pit mining (MWC 2013). The frequency and ubiquity of conflict as a product of Canadian nation-building projects follows from the fact that Canadian mining companies comprise a large "statistical share of the international mining sector," and are responsible for "more than four times as many incidents" of human rights abuses as other significant mining countries, including the United Kingdom and Australia (Canadian Centre for the Study of Resource Conflict 2009: 10).

With the advent of the new Canadian imperialism and the unbundling of borders, new forms of belonging emerge as the dissemination of ideas and concerns regarding social justice and environmental protection intensify during a process Palacios (2004: 38) refers to as "the globalization of civil society." A civil society NGO of particular interest is MiningWatch Canada (MWC). The remainder of this paper will discuss the citizenship practices and ideals of MWC, including a close reading of a case of Canadian mining in Mexico. ${ }^{11}$ This case criticizes the deployment of middling technocrats and corporate citizens to reshape resource governance abroad in support of Canadian nation-building. The document is important because it challenges the citizenship regime advanced by the Canadian state and offers alternative proposals reminiscent of a sustainable citizenship and ecological political economy.

MWC was formed in 1999 as part of a collective effort of aboriginal, social justice and environmental groups in Canada. MWC expresses an internationalist spirit, forging networks connecting civil society in and beyond the state "to bring about reforms that will prevent and punish irresponsible mining practices and address existing and past abuses" (MWC 2012: 1). Based on some of these descriptions, and a perusal of

11. NGO staff of two different organizations co-authored the report analyzed in this section. No academic research could be found on this community and movement. 
their Annual Reports (2010; 2011; 2012), it can be argued MWC more accurately promotes the Canadian identity and values crafted in the SFT (2013) than the corporate citizens the state nurtures. In particular, MWC practices "mutual interdependence" (SFT 2013: 1), and seeks to ensure that "human dignity" is respected by promoting "what is right and good in the world" (SFT 2013: 19). This is achieved through international solidarity work, including participating in important fact-finding delegations (initiated by impacted communities themselves) that call into question corporate citizenship regimes and highlight the active role played by state actors in ensuring the operation of nation-building projects.

\section{Corporate Citizenship Regimes in Practice: Violence and Impunity in Mexico}

An important assessment written by Moore and Colgrove (2013) provides detailed insight into the common issues and sets of relationships representing Canadian mining operations around the world. This report documents the corruption and violence imposed in Chicomuselo, a municipality located in the Chiapas region of Mexico. The report reveals that not only did state actors (diplomats at the Canadian Embassy) unconditionally support Blackfire, but they did not ensure that the CSR policies implemented by the Government of Canada in 2009 were followed to safeguard the rights of communities located in close proximity to the Payback mine (Moore and Colgrove 2013). According to the report's findings, the problems associated with the project began in 2007 with a lack of proper consultation and consent between Blackfire and the two local communities of Ejido Grecia and Ejido Nueva Morelia (Moore and Colgrove 2013). Speaking with the locals, Moore and Colgrove (2013: 28) reported that "little or no consultation" had occurred in the communities of Ejido Grecia and Ejido Nueva Morelia despite Mexican agrarian law stipulating that land transfers must be approved by a General Assembly. The Embassy supported Blackfire despite being aware of this lack of consultation. On this issue, the Embassy's only attempt at engaging Blackfire in CSR initiatives was by informing the company of the Mining Task Force (MTF), an Embassy-led initiative used to engage companies in CSR matters (Moore and Colgrove, 2013). This is an insufficient means of addressing the complex issue of community consultation as the Embassy admits that the MTF's mandate is to merely "promote and support the interests of Canadian mining companies... through public relations outreach" (Moore and Colgrove 2013: 6). This excerpt from an Embassy communication confirms the lack of currency the MTF has in responsibly engaging with potential or affect- 
ed communities, as well as confirming the active role the state plays in securing nation-building projects.

In addition to a lack of consultation, the life of the Blackfire project was mired by violence and corruption. Mariano Abarca, a local antimining activist, was murdered in 2009 and the three suspects - all with connections to Blackfire - were detained. Mariano's death came after a series of complaints from peaceful protestors about "armed [Blackfire] workers, threats, and intimidation" (Moore and Colgrove 2013: 29). Despite the Embassy's awareness of the tensions between the practices of Blackfire employees and the local communities (manifesting in a series of protests, and even a sit-in at the Canadian Embassy), Embassy staff "failed to distance themselves from the company, acting in Blackfire's interests rather than considering all affected parties" (Moore and Colgrove 2013: 29). This is especially evident in the lack of initiative taken by the Embassy in acknowledging this conflict, in supporting and calling for an investigation, and in reconsidering its support to Blackfire.

The facts emerging in this case study suggest that: (1) Canadian mining companies such as Blackfire do not follow the voluntary human rights and sustainable policies outlined in BCA (2009) ${ }^{12}$ and (2) Canadian middling technocrats (Embassy personnel) actively promote the pursuit of profit despite evidence that contradicts both the policy of the Government of Canada and the values that its citizens are to represent. A telling evaluation of these sets of practices appears in a public conversation Mariano Abarca had with an Embassy public relations official. This conversation occurred during a 36-hour protest in front of the Canadian Embassy (Moore and Colgrove 2013: 11). On video, Abarca states "some of us in the movement have received threats and we do not think it is fair that foreigners come in creating conflict while taking the wealth back to their country" (Moore and Colgrove 2013:11).

Following the fact-finding mission, Moore and Colgrove (2013: 27) criticized the Embassy's approach in handling the Blackfire case, claiming it as contrary to the state's CSR policy and not reflective of its officially stated values. The authors made several recommendations for a more robust regulatory regime. The most important recommendations include (1) that BCA (2009) be replaced with legislation regulating nation-building practices according to international legal standards (human rights, labour and environmental) and respecting the right of self-determination for Indigenous peoples, as well as the right to free, prior and informed consent and (2) when supporting Canadian mining companies, government actors only do so if the "democratic and participatory

12. Because this report and event pre-dates the DBCW (2014) strategy, it is not considered in this discussion. 
decision-making processes of non-Indigenous communities" occur prior to development, and when they do, that the result be respected even if contrary to the interests of the company (Moore and Colgrove 2013: 32). It is based on these recommendations, and the criticism MWC expressed throughout its report, that the Canadian government's citizenship regime is called into question. In solidarity with local communities across borders, MWC amplifies the voices of communities and movements demanding change from below.

\section{Greening Citizenship Regimes: Prospects and Opportunities}

If corporate citizenship is a vehicular idea devoid of substance, what meaningful forms of citizenship can take its place in light of existing practices? This is not necessarily to propose the construction of a stat$i c$ and singular model of citizenship. After all, citizenship is fluid and subject to transformation (Jelin 2000; Jenson 2001; Valencia Sáiz 2005; Rasch 2012). Nor does this suggest that the purpose of thinking through citizenship is instrumental (Latta 2007; Gabrielson 2008); that it is a particular means (green citizenship) to a predetermined end (ecologically healthy societies). However, if we accept the proposition that citizenship is a set of practices we must consider what types of citizenship reflect existing practices. In an era of globalization marked by imperialism, where capital, resources, ideas and bodies flow from one container to another, impacting the landscapes and practices of different peoples in different places, it is crucial to incorporate a networked understanding into our thinking of citizenship and its regime. This is to say citizenship must: (1) be post-cosmopolitan to the degree that it is beyond any one nation state and open to deliberation (2) recognize that the configuration of citizenship is fluid, contested and a product of dense networks (Latta 2013) informed by the mobile policies carried by intermediary technocrats and finally (3) be rooted in the sense that it can be scaled back to its container to inform, shape and further deliberate a flexible citizenship regime grounded in environmental justice.

The above proposal can be appropriated in various forms. A diluted form of this type of citizenship is one proposed by the Government of Canada. In 2001, Environment Canada developed environmental citizenship as a concept, but framed it as an individual duty to act "responsibly and positively toward our environment" (Agyeman and Evans 2006: 199). The concept of environmental citizenship defined as such is problematic because it downloads environmental responsibility on individuals, perpetuating a belief that changing light bulbs or purchasing green products will halt and reverse environmental degradation. This position 
ignores both a capitalist economy driven by accumulation by dispossession and a state that is equally committed to imperial conquest; together, they generate ecocidal tendencies, often on the basis of historical experience. This conceptualization of environmental citizenship is also dangerous because it falls within the purview of corporate citizenship by engaging in a weak and narrow politics of corporate social responsibility instead of a broader practice challenging contemporary ways of doing political economy and citizenship (regimes).

A conceptualization of citizenship reflective of the approach MWC and various civil society organizations challenging nation-building practices at home and abroad is sustainability or critical citizenship. ${ }^{13}$ Barry (2006) conceives of critical citizenship as a shift from the aforementioned narrow approach of environmental citizenship. Critical citizenship is an "ambitious, multifaceted and challenging mode of green citizenship, which focuses on the underlying structural causes of environmental degradation and other infringements of sustainable development such as human rights abuses or social justice" (Barry 2006: 24). Defined this way, critical citizenship moves beyond environmental concerns to include democracy, governance, participation and quality of life (Barry 2006). This is reflective of the forms of citizenship in Latin America, particularly around anti-mining struggles wherein citizenship is shaped and given meaning through the practices associated with natural resource governance (Rasch 2012). A major component of critical citizenship is resistance work requiring "corrective or oppositional work" to challenge the structural causes of unsustainability (Barry 2006: 32). Barry (2006) qualifies this point by arguing that citizens have a right and duty to challenge dominant state and economic actors perpetuating unsustainable development (Barry 2006). Defined this way, critical citizenship is a seemingly fruitful conceptualization of citizenship and is reflective of the practices of civil society organizations such as MWC and the community voices they seek to amplify.

Although MWC focuses on nation-building projects, it does not do this from a strictly environmental framework. On the contrary, MWC's Annual Reports $(2010 ; 2011 ; 2012)$ appear to consistently represent the "full spectrum" (Barry 2006: 32) of critical citizenship: they are critical of nation-building projects because of their effects on individuals, communities and environmental well-being. It is because of these negative effects that MWC seeks to correct the problem by transforming state

13. Barry's (2006) sustainability or critical citizenship sheds some of the problematic elements of traditional republican traditions, including: an authoritarian state-centric approach, a gender bias and the promotion of compulsory sustainability activities. 
policies through stronger regulation, if not actively halt mining practices (MWC n.d.). It should be noted that MWC does this type of work in concert with "subaltern political voices" (Latta 2007: 390) calling on Canadian companies and even the state to cultivate "democratic modes of collective socio-ecological being” (Latta 2007: 390). Overall, critical citizenship seems to more accurately reflect the Canadian identity and values specified in the SFT (2013: 19) by engaging in democratic processes respecting human dignity and defend "what is right and good in the world." ${ }^{\prime 14}$

A few questions remain: is sustainability or critical citizenship a coherent conceptualization, or is it at risk of becoming, like corporate citizenship, a vehicular idea with little substance? The concept of sustainability appears to be equally as mutable and ambiguous, and this is purposive: it helps move the concept across different policy-making sites and institutions, risking depoliticization (McKenzie et al. 2015). Furthermore, in what ways might the flexibility of this term hinder the movement challenging corporate impunity and Canadian mining practices abroad? How do NGOs and social movements working in solidarity with communities affected by Canadian mining operations understand citizenship as practice, and what values, discourses and identities inform this? How is the mobility of sustainable practices produced, performed, maintained, repaired or resisted (Sheller 2014)? Thinking through these questions and similar insights offers an opportunity for future research to explore and explain the construction and mobile effects of Canadian citizenship regimes from below.

\section{Conclusion}

The mobilities turn proposes that social scientists dispense of sedentarist theories of the social world (Sheller and Urry 2006). In response to this, scholars writing on policy mobilities (Temenos and McCann 2013; Peck 2011; Peck 2012) trace the movement of policies among "unbounded states" and state actors while emphasizing the importance of "territorial fixity and embeddedness" (Temenos and McCann 2013: 346-347). A focus on territorial fixity has led new mobilities research to examine the forms of governance enabling movement, as well as the ideologies and

14. I do not mean to suggest here that activists and civil society organizations must conform to identities and values expressed in the SFT (2013) to construct an 'authentic' and 'Canadian' identity. In fact, these values and identities need to be re-appropriated and shed of their nationalist character, as they are integral to building a global citizenship regime based on relationships of solidarity rooted in non-domination. 
meanings shaping them (Sheller 2014). As the Blackfire case indicates, this paper has contributed to this research effort by examining the Canadian citizenship regime as an imperial system of governance pushing both policy, middling technocrats and the vehicular idea of corporate citizenship abroad for the purpose of Canadian nation-building. This vehicular idea is able to move, alter and diffuse policy from point A to B in part due to the state discourses preparing it for travel. This departs from traditional research on natural resources and mobility (Campbell 2012; Pedersen and Bunkenborg 2012) and contributes to studies of vehicular ideas by moving away from local and urban contexts (Baker and Evans 2016; McKenzie et al. 2015; Peck 2012) to a multi-scale assessment of the role of corporate citizenship in policy mobility.

The state discourses examined in this paper are saturated with notions of Canadian identity, values, and what it means to be an ideal citizen, transmitting carefully constructed and historically binding citizenship regimes. They produce a narrative representing Canadians as engaging in nation-building projects, promoting human dignity, freedom and democracy abroad. Contrary to the argument that the Canadian "state is not identified as taking a leadership role in the creation of the new economy" (Brodie 2002a: 62), this paper has argued that the Canadian state not only takes an active role in forming the conditions for the expansion of nation-building projects, but also actively participates in networks reshaping policies abroad to secure the flow of capital and minerals. Canadian policy prescriptions at once influence the conduct of corporate actors in dense networks of interactions and attempt to manage the risk posed by anti-mining struggles. Although organizations such as MWC challenge state-sanctioned practices, what remains to be seen is the viability, articulation and large-scale practice of an alternative, inclusive and democratic citizenship regime.

\section{REFERENCES}

Agyeman, Julian and Bob Evans. 2006. "Justice, Governance, and Sustainability: Perspectives on Environmental Citizenship from North America and Europe.” Pp. 185-206 in Environmental citizenship, edited by A. Dobson, and D. Bell. Cambridge, MA: MIT Press.

Anderson, Benedict. 2006. Imagined Communities. London: Verso.

Baker, Tom and Joshua Evans. 2016. "“Housing First' and the Changing Terrains of Homeless Governance.” Geography Compass 10(1): 25-41.

Barry, John. 2006. "Resistance is Fertile: From Environmental Citizenship to Sustainability Citizenship." Pp. 21-48 in Environmental citizenship, edited by A. Dobson, and D. Bell. Cambridge, MA: MIT Press. 
Brodie, Janine. 2002a. "Three Stories of Canadian Citizenship.” Pp. 43-66 in Contesting Canadian Citizenship: Historical Readings, edited by R. Adamoski, D.E. Chunn, and R. Menzies. Toronto, ON: Broadview Press.

Brodie, Janine. 2002b. "Citizenship and Solidarity: Reflections on the Canadian Way." Citizenship Studies 6(4): 377-394.

Brodie, Janine. 2004. "Introduction: Globalization and Citizenship Beyond the National State." Citizenship Studies 8(4): 323-332.

Burgess, William. 2002. "Canada's location in the world system: Reworking the debate in Canadian political economy." Ph.D. dissertation. Department of Geography, University of British Columbia.

Campbell, Jeremy M. 2012. "Between the Material and Figural Road: The Incompleteness of Colonial Geographies in Amazonia." Mobilities 7(4): 481-500.

Canadian Centre for the Study of Resource Conflict. 2009. Corporate Social Responsibility: Movements and Footprints of Canadian Mining and Exploration Firms in the Developing World. Retrieved November 15, 2013 (http://miningwatch.ca/sites/default/files/CSR_Movements_and_Footprints.pdf).

Coumans, Catherine. 2010. "Alternative Accountability Mechanisms and Mining: The Problems of Effective Impunity, Human Rights, and Agency." Canadian Journal of Development Studies 30(1-2): 27-48.

Coumans, Catherine. 2012. "Mining, Human Rights and the Socially Responsible Investment Industry: Considering Community Opposition to Shareholder Resolutions and Implications of Collaboration." Journal of Sustainable Finance \& Investment 2(1): 44-63.

Do, Trinh Theresa. 2014. “Ottawa's Responsible Mining Review Awaited by NGOs.” CBC. Retrieved April 29, 2015 (http://www.cbc.ca/news/politics/ottawa-s-responsible-mining-review-awaited-by-ngos-1.2543080).

Dougherty, Michael. 2013. "The Global Gold Mining Industry: Materiality, Rent-seeking, Junior Firms and Canadian Corporate Citizenship." Competition and Change 17(4): 339-354.

Gabrielson, Teena. 2008. "Green Citizenship: A Review and Critique." Citizenship Studies 12(4): 429-446.

Global Affairs Canada. N.d.-a Corporate Social Responsibility. Retrieved April 30, 2015 (http://www.international.gc.ca/trade-agreements-accordscommerciaux/topics-domaines/other-autre/csr-rse.aspx?lang=eng).

Global Affairs Canada. N.d.-b. Our Priorities. Retrieved March 29, 2016 (http:// www.international.gc.ca/department-ministere/priorities-priorites. aspx?lang=eng).

Global Affairs Canada. 2009. Building the Canadian Advantage: A Corporate Social Responsibility (CSR) Strategy for the Canadian International Extractive Sector. Retrieved November 21, 2013 (http://www.international. 
gc.ca/trade-agreements-accords-commerciaux/topics-domaines/otherautre/csr-strat-rse-2009.aspx?lang=eng)

Global Affairs Canada. 2014. Doing Business the Canadian Way: A Strategy to Strengthen Canada's Extractive Sector Abroad. Retrieved December 5, 2014 (http://www.international.gc.ca/trade-agreements-accords-commerciaux/assets/pdfs/Enhanced_CS_Strategy_ENG.pdf).

Gordon, Todd and Jeffery Webber. 2008. "Imperialism and Resistance: Canadian Mining Companies in Latin America." Third World Quarterly 29(1): 6387.

Holden, Michael. 2008. Overview of Canadian Foreign Direct Investment. Library of Parliament Research Publications. PRB 0833E. Retrieved November, 21, 2013 (http://www.parl.gc.ca/content/lop/researchpublications/prb0833-e.pdf).

Jackson, Sara L. 2015. "Imagining the Mineral Nation: Contested Nation-building in Mongolia." Nationalities Papers 43(3): 437-456.

Jelin, Elizabeth. 2000. “Towards a Global Environmental Citizenship?” Citizenship Studies 4(1): 47-63.

Jennings, Will, Shaun Bevan and Peter John. 2011. "The Agenda of British Government: The Speech from the Throne, 1911-2008." Political Studies 59: 74-98.

Jenson, Jane. 2001. "Social Citizenship in the $21^{\text {st }}$ Century: Challenges and Options." Presented at the 2001 Timlin Lecture at the University of Saskatchewan, February 5, Saskatoon, SK. Retrieved April 15, 2015 (www. cprn.org/documents/26232_en.pdf).

Jenson, Jane. 2007. “The European Union's Citizenship Regime. Creating Norms and Building Practices." Comparative European Politics (5): 53-69.

John, Peter and Will Jennings. 2010. "Punctuations and Turning Points in British Politics: The Policy Agenda of the Queen's Speech, 1940-2005." British Journal of Political Science 40: 561-586.

Kamphuis, Charis. 2012. "Canadian Mining Companies and Domestic Law Reform: A Critical Legal Account." German Law Journal 13(9): 1456-1486.

Keck, Margaret E. and Kathryn Sikkink. 1998. Activists Beyond Border: Advocacy Networks in International Politics. Ithaca, NY: Cornell University Press.

Klassen, Jerome. 2009. "Canada and the New Imperialism: the Economics of a Secondary Power." Studies in Political Economy 83: 163-190.

Klassen, Jerome. 2014. Joining Empire: The Political Economy of the New Canadian Foreign Policy. Toronto: University of Toronto Press.

Larner, Wendy and Nina Laurie. 2010. Travelling Technocrats, Embodied Knowledges: Globalising Privatisation in Telecoms and Water. Geoforum 41 18-226. 
Latta, Alex. 2007. "Locating Democratic Politics in Ecological Citizenship." Environmental Politics 16(3): 377-393.

Latta, Alex. 2013. "Locating Nature's Citizens: Latin American Ecologies of Political Space.” Citizenship Studies 17(5): 566-580.

Matten, Dirk and Andrew Crane. 2005. "Corporate Citizenship: Toward an Extended Theoretical Conceptualization." Academy of Management Review 3(1): 166-179.

McAllister, Mary Louise. 2007. "Shifting Foundations in a Mature Staples Industry: a Political Economic History of Canadian Mineral Policy." Canadian Political Science Review 1: 73-90.

McKenzie, Marcia, Andrew Rieler and Rebecca McNeil. 2015. "Education Policy Mobility: Reimagining Sustainability in Neoliberal Times." Environmental Education Research 21(3): 319-337.

McLennan, Gregor. 2004. "Travelling with Vehicular Ideas: the case of the Third Way." Economy and Society 33(4): 484-499.

MiningWatch Canada. n.d. “About Us.” Retrieved November 29, 2013 (http:// www.miningwatch.ca/about-us-1).

MiningWatch Canada. 2010. “Annual Report 2010.” Retrieved November 15, 2013 (http://www.miningwatch.ca/miningwatch-canada-annual-reports).

MiningWatch Canada. 2011. “Annual Report 2011.” Retrieved November 15, 2013 (http://www.miningwatch.ca/miningwatch-canada-annual-reports).

MiningWatch Canada. 2012. “Annual Report 2012.” Retrieved November 15, 2013 (http://www.miningwatch.ca/miningwatch-canada-annual-reports).

MiningWatch Canada. 2013. "Backgrounder: A Dozen Examples of Canadian Mining Diplomacy.” Retrieved November 15, 2013 (http://www.miningwatch.ca/article/backgrounder-dozen-examples-canadian-miningdiplomacy).

Moore, Jennifer and Gillian Colgrove. 2013. "Corruption, Murder and Canadian Mining in Mexico: The Case of Blackfire Exploration and the Canadian Embassy." Retrieved November 15, 2013 (http://www.miningwatch.ca/ sites/www.miningwatch.ca/files/blackfire_embassy_report_eng_0.pdf)/.

Natural Resources Canada. 2012. The Geographical Distribution of Canada's Mining Assets. Retrieved November 15, 2013 (http://www.nrcan.gc.ca/ minerals-metals/publications-reports/4425).

Natural Resources Canada. 2013. Mining Sector Performance Report 19982012. Retrieved November 15, 2013 (http://www.nrcan.gc.ca/sites/www. nrcan.gc.ca/files/mineralsmetals/files/pdf/MSP-report-eng.pdf).

Osborne, Thomas. 2004. "On Mediators: Intellectuals and the Ideas Trade in the Knowledge Cociety." Economy and Society 33(4): 430-447.

Palacios, Juan José. 2004. "Corporate Citizenship and Social Responsibility in a Globalized World.” Citizenship Studies 8(4): 383-402. 
Peck, Jamie and Nik Theodore. 2010. "Mobilizing Policy: Models, Methods, and Mutations." Geoforum 41: 169-174.

Peck, Jamie. 2011."Geographies of Policy: From Transfer-Diffusion to Mobilitymutation." Progress in Human Geography 35(6): 773-797.

Peck, Jamie. 2012. "Recreative City: Amsterdam, Vehicular Ideas and the Adaptive Spaces of Creativity Policy." International Journal of Urban and Regional Research 36(3): 462-485.

Pedersen, Morten Axel and Mikkel Bunkenborg. 2012. "Roads that Separate: Sino-Mongolian Relations in the Inner Asian Desert." Mobilities 7(4): 555-569.

Pedersen, Alexandra. 2014. "Landscapes of Resistance: Community Opposition to Canadian Mining Operations in Guatemala." Journal of Latin American Geography 13(1): 187-214.

Penrose, Jan, and Richard C. Mole. 2008. "Nation-states and National Identity." In The SAGE handbook of political geography, edited by K. R. Cox, M. Low, and J. Robinson, 271-284. London: Sage.

Rasch, Elisabet Dueholm. 2012. "Transformation in Citizenship: Local Resistance against Mining Projects in Huehuetenango (Guatemala).” Journal of Developing Societies 28(2): 159-184.

Sheller, Mimi. And John Urry. 2006. "The New Mobilities Paradigm.” Environment and Planning 38(2): 207-226.

Sheller, Mimi. 2014. "The New Mobilities Paradigm for a Live Sociology.” Current Sociology Review 63(6): 789-811.

Shipley, Tyler. 2013. "The New Canadian Imperialism and the Military Coup in Honduras." Latin American Perspectives 40(5): 44-61.

Speech from the Throne. 2013. Seizing Canada's Moment: Prosperity and Opportunity in an Uncertain World. Retrieved November 15, 2013 (http:// www.speech.gc.ca/sites/sft/files/SFT-EN_2013_c.pdf).

Temenos, Cristina and Eugene McCann. 2013. "Geographies of Policy Mobilities." Geography Compass 7(5): 344-357.

Thompson, Grahame. 2005. "Global Corporate Citizenship: What Does it Mean?" Competition \& Change 9(2): 131-152.

Tremblay, Pascal. 2014. Direct Investment Between Canada and the World. Library of Parliament Research Publication No. 2014-26-E. Retrieved April 30, 2015 (http://www.lop.parl.gc.ca/content/lop/ResearchPublications/201426-e.pdf).

Urry, John. 2000. Sociology Beyond Societies: Mobilities for the Twenty-first Century. London: Routledge.

Valencia Sáiz, Angel. 2005. "Globalisation, Cosmopolitanism and Ecological Citizenship.” Environmental Politics 14(2): 163-178. 
Yashar, Deborah J. 2005. Contesting Citizenship in Latin America: The Rise of Indigenous Movements and the Postliberal Challenge. Cambridge: Cambridge University Press.

\section{ACKNOWLedgements}

This research was supported by the Social Sciences and Humanities Research Council of Canada. An earlier version of this manuscript was presented at the 2014 Annual Conference of the Canadian Sociological Association (CSA) in St. Catherines, Ontario. I would like to thank Daiva Stasiulis and Jacqueline Kennelly for their mentorship and encouragement to develop this paper for publication. I would also like to thank Stephanie Sodero and Nicholas Scott for their support throughout the publication process, and the three anonymous reviewers for providing valuable feedback.

Max Chewinski is a PhD student in Sociology at the University of British Columbia. His broad research interests encompass social movements, environmental sociology, citizenship studies and political economy.

E-mail: max.chewinski@alumni.ubc.ca 
374 C Canadian Journal of Sociology/Cahiers Canadiens de sociologie 41(3) 2016 